\title{
Contradições entre as medições de audiência em tempo real e consolidada: um problema para a programação ao vivo da Tv brasileira
}

\section{Valdecir Becker ${ }^{1}$}

Recibido: 2013-11-25

Envío a pares: 2013-12-14
Aprobado por pares: 2014-01-30

Aceptado: 2014-02-05

DOI: 10.5294/pacla.2014.17.3.6

Para citar este artículo / To reference this article / Para citar este artigo

Becker, V. Septiembre de 2014. Contradições entre as medições de audiência em tempo real e consolidada: um problema para a programação ao vivo da TV brasileira. Palabra

Clave 17 (3), 717-748. DOI: 10.5294/pacla.2014.17.3.6

\section{Resumo}

Este artigo faz uma comparação estatística entre os índices de audiência minuto a minuto e consolidados, medidos na Grande São Paulo, principal mercado televisivo do Brasil. A partir da necessidade de informações para a tomada de decisões na programação ao vivo, o artigo questiona a validade dos dados minuto a minuto. Constata-se que todas as informações relativas à medição minuto a minuto são corrigidas nos dados consolidados e conclui-se que os índices não são críveis para pautar as decisões sobre os programas ao vivo.

\section{Palavras-chave}

Medição de audiência, televisão, programação, mercado brasileiro (Fonte: Tesauro da Unesco).

1 Universidade Federal da Paraíba (UfpB), Brasil. valdecir@ci.ufpb.br 


\section{Las contradicciones entre los índices de audiencia en tiempo real y consolidados: un problema de programación en vivo en la televisión brasileña}

\section{Resumen}

Este artículo es una comparación estadística entre los índices de audiencia en tiempo real y los datos consolidados, medidos en São Paulo, el mercado de televisión más importante de Brasil. A partir de la necesidad de información para tomar decisiones sobre la programación en vivo, el artículo cuestiona la validez de los tipos de medidas en tiempo real. Toma nota de que toda la información en tiempo real se actualizan en las calificaciones consolidadas, y llega a la conclusión de que las mediciones en tiempo real no son creíbles para las decisiones políticas sobre los programas en vivo.

\section{Palabras clave}

Medición de audiencias, programación de televisión, mercado brasileño (Fuente: Tesauro de la Unesco). 


\section{Contradictions between Real-time and Consolidated Audience Ratings: A Problem for Live Programming on Brazilian Television}

\section{Abstract}

This article offers a statistical comparison between real-time and consolidated audience ratings measured in São Paulo, Brazil's most important television market. Based on the need for information to make decisions on live programming, the article questions the validity of ratings measured in real time and notes that all real-time information is updated in consolidated ratings. The conclusion is that real-time ratings are not credible for policy decisions on live programming.

\section{Key words}

Audience measurement, television programming, Brazilian market (Source: UNESCO Thesaurus). 


\section{Introdução}

As emissoras de televisão costumam mesclar produções ao vivo com outras gravadas. No Brasil há uma grande disparidade quando se considera se o foco da programação é ao vivo ou gravado. Levantamento feito pelo autor desta pesquisa em junho de 2013 mostrou que, no caso da Tv Record, vice-líder em audiência no país, $56 \%$ da programação ao longo do mês foi ao vivo. A tv Globo, líder de audiência, tinha $28 \%$. Já o Sistema Brasileiro de Televisão (sBT), terceiro colocado, $20 \%$.

Uma característica da programação ao vivo é a necessidade da tomada de decisões em função do comportamento da audiência. São decisões estratégicas tomadas enquanto o programa está no ar. Essas decisões visam: a) manter a audiência do programa; b) aumentar a audiência, tanto para agregar pessoas que acabaram de ligar a TV quanto trazer telespectadores de outros programas/emissoras.

Um recurso importante e estratégico para a tomada de decisão referente à condução do programa ao vivo é o comportamento da audiência em tempo real. Ou seja, é necessário conhecer se há oscilações da audiência. Com essa informação, são decididas alterações na estrutura do programa, como a duração e a sequência de determinadas atrações, bem como a distribuição dos intervalos comerciais. Por exemplo: um cantor pode ficar mais tempo no ar se a audiência estiver crescendo ou cantar menos canções do que o previsto se a audiência cair. Considerando o perfil da programação, a TV Record tem uma demanda maior por informações em tempo real sobre o comportamento da audiência da TV Globo e do SBT.

A principal fonte de informação sobre o comportamento em tempo real do telespectador, utilizada hoje pelos departamentos de programação das emissoras para a tomada de decisão, é a audiência minuto a minuto (também chamada de tempo real ou simplesmente prévia), disponibilizada pelo Instituto Brasileiro de Opinião Pública e Estatística (Ibope), empresa que detém o monopólio da pesquisa de audiência no Brasil. Com base nessas informações, diretores de programação tomam todas as principais decisões relativas tanto à parte artística quanto à comercial. 
Portanto, em programas ao vivo, os índices minutos a minuto são de extrema importância. No entanto, verifica-se que os índices dessa audiência são corrigidos constantemente na audiência consolidada, fornecida pelo Ibope no dia seguinte à medição (também chamada de audiência overnight). Essas variações costumam ser tanto negativas quanto positivas, ou seja, a audiência do programa pode ser maior ou menor do que os dados em tempo real demonstravam enquanto o programa estava no ar. Variações desse tipo comprometem as decisões tomadas durante o programa, o que pode impactar negativamente a audiência e as relações comerciais da emissora de TV com os anunciantes.

O presente trabalho faz uma análise estatística comparativa dos dados fornecidos pelo Ibope referentes às audiências minuto a minuto e consolidada. São realizadas comparações entre os índices de audiência das três emissoras nacionais de maior audiência — TV Globo, Record, e SBT — considerando a evolução dos dados ao longo de 2012. Foi feito um levantamento de dados referente a todo o ano, o qual buscou identificar se existiram variações entre a audiência consolidada e a prévia e em qual momento essas variações mais ocorreram. Também identifica se a variação é positiva ou negativa e se há relações com os dados das outras emissoras citadas. $\mathrm{O}$ artigo está estruturado da seguinte forma: a próxima seção faz uma discussão sobre a importância da medição da audiência e a medição no Brasil; na seção três são apresentados os índices de audiência de 2012. As seções quatro e cinco trazem a análise dos dados e as conclusões do estudo.

\section{A medição da audiência}

McQuail (1997, p. 1) define audiência como "o termo coletivo para os 'recebedores' no modelo sequencial do processo de comunicação de massa”. Ou seja, são os leitores da mídia impressa, os ouvintes do rádio e os telespectadores da televisão. Trazendo o conceito para a atualidade, engloba também os usuários das tecnologias digitais de comunicação, como a internet (Bermejo, 2007).

A necessidade de medir e auferir a audiência nasce com os meios de comunicação. Larrañaga (1998) explica que dados sobre a quanti- 
dade de espectadores são fundamentais para qualquer mídia, especialmente para a televisão. Para o autor, não faz sentido a atividade de uma estação de TV sem consumidores. Além disso, as audiências, de forma indireta, proporcionam financiamentos através das agências de publicidade. Apesar da sua dificuldade, o conhecimento da audiência das mídias audiovisuais é imprescindível para o desenvolvimento da indústria da comunicação.

Para Iglesias (1985), nenhum sistema, e em especial nenhum sistema em que a comunicação tenha um papel vital, pode funcionar sem uma investigação de audiência ou feedback. Durante todo o século $\mathrm{xx}$, a crescente participação de empresas privadas que anunciavam seus produtos no rádio e na televisão foi diretamente proporcional ao desenvolvimento de ferramentas de medição da audiência. "Deste modo, a pesquisa de audiência nasce como um instrumento de controle das atividades publicitárias" (Bermejo, 2007, p. 34).

Além disso, em modelos de negócio baseados na remuneração pela publicidade, em que o conteúdo é oferecido gratuitamente, a pressão por conhecer a audiência e para desenvolver ferramentas de medição, fica mais forte à medida que as informações sobre a recepção se tornam mais escassas. $\mathrm{O}$ aumento do alcance de transmissão das mídias traz mais consumidores para o conteúdo, o que demanda dados quantitativos sobre o perfil e o comportamento, com complexidade diretamente proporcional ao crescimento do tamanho da audiência.

A televisão é essencialmente um meio de comunicação e, como tal, precisa de audiência para existir. Iglesias (1985) lembra que as empresas de televisão, como toda radiodifusão, apresentam características próprias. A diferença para outras atividades industriais e comerciais está na característica de o setor de radiodifusão assumir plenamente as funções de produção, comercialização, distribuição. Portanto, trata-se de um bem de natureza imaterial, no qual a produção não se ajusta rigidamente à demanda. Os custos de um programa de radiodifusão são independentes da quantidade de destinatários. 
Essa característica gera uma relação de consumo totalmente atípica, uma vez que os custos de produção e distribuição pouco interferem, e muito menos definem, os preços de comercialização. A venda é feita considerando as possibilidades de audiência, projetadas ou auferidas. Trata-se de um modelo de negócios no qual as emissoras de TV vendem índices de audiência para os anunciantes e abstraem, assim, a produção e a recepção dos programas (Cruz, 2008).

Dessa forma, as medições da audiência suprem uma necessidade imediata das emissoras de TV, que precisam legitimar, de alguma forma, os valores praticados nas negociações de cotas de patrocínio e venda de espaço publicitário. Sem essa legitimação, faltariam inclusive parâmetros de definição de valores monetários para diferentes programas ou canais.

O conhecimento da audiência é praticamente o único critério válido e aceito para a venda de espaços (tempos) às agências de publicidade e anunciantes, que são quem financiam em grande parte, ou totalmente, o rádio e a televisão. Portanto, a análise das audiências vem a ser um dos elementos básicos de gestão, que permite contrastar a eficácia da difusão de informações e de qualquer outro tipo de conteúdos orientados à formação ou ao mero entretenimento (Iglesias, 1985).

\section{Medição da audiência no Brasil}

No Brasil, a medição da audiência na TV é realizada pelo Ibope, uma empresa privada que comercializa os dados referentes à audiência para emissoras de TV e agências de publicidade. A tecnologia predominante para coleta dos dados é o people meter, um audímetro conectado à TV, que envia as informações continuamente por sinais de rádio ou aparelho celular embutidos no dispositivo de medição (Ibope, 2013).

As informações sobre canal são mapeadas automaticamente através da radiofrequência sintonizada. Já os dados sobre os telespectadores são inseridos através de um controle remoto com 16 botões numerados, divididos em duas cores (o controle remoto varia de país para país). Cada botão corresponde a um canal de medição do aparelho e cada número corresponde 
a um morador da casa. Ou seja, cada morador possui um número específico, que deverá ser pressionado quando a TV for ligada, o que o identificará para gerar os índices de audiência.

O Ibope trabalha com dois sistemas de envio de informações: minuto a minuto e overnight. No caso do minuto a minuto, as informações sobre o comportamento da audiência e sobre o status do domicílio são enviadas pelo people meter por celular a cada minuto para a central do Ibope, que as disponibiliza a emissoras e agências de publicidade no minuto seguinte à aferição. Esses números são consolidados durante a noite, com informações definitivas fornecidas no dia seguinte. Fazem parte desse tipo de coleta de informações as praças: Grande São Paulo, Grande Rio de Janeiro, Grande Belo Horizonte e Grande Porto Alegre².

As demais cidades possuem um sistema chamado overnight, no qual os dados são armazenados localmente e transmitidos por telefone durante a madrugada. Os dados consolidados são distribuídos aos assinantes na manhã seguinte à consolidação.

O mercado televisivo mais importante do Brasil é São Paulo, que, na época do levantamento das informações para o presente estudo, dispunha de uma amostra de 760 residências que enviavam informações minuto a minuto, o que é considerado tempo real na medição de audiência (Jauset, 2000). Essa base de dados é utilizada como guia pelas emissoras de TV que, por sua vez, fazem o planejamento imediato da programação. Na prática, devido ao grande peso econômico e à concentração de emissoras e agências de publicidade na cidade ${ }^{3}$, todas as informações relativas à audiência da Tv brasileira tomam por base a medição realizada na Grande São Paulo.

No total, há quatro mil pontos de medição no país, distribuídos em 14 cidades. Destes, 3.765 geram informações. Os demais aparelhos ficam

2 A medição da audiência é feita nas regiões metropolitanas dessas cidades, o que inclui os municípios conturbados.

3 Todas as emissoras de TV têm sede na cidade de São Paulo, onde ficam também as cabeças de rede nacionais. A única exceção é a TV Globo, cuja cabeça de rede nacional fica no Rio de Janeiro, mas que tem geradora em São Paulo. Além disso, as oito maiores agências de publicidade também possuem suas sedes em São Paulo, o que concentra todo o mercado publicitário e televisivo nessa cidade. 
como backup, caso ocorram problemas técnicos. Cada ponto de medição pode ter até quatro aparelhos people meter.

A metodologia para a medição de audiência de televisão é denominada painel, que representa um mesmo grupo fixo de domicílios acompanhado ao longo de, aproximadamente, quatro anos. Os domicílios que fazem parte da amostra são selecionados estatisticamente, usando como base o censo demográfico realizado pelo Instituto Brasileiro de Geografia e Estatística (IBGE). Além disso, o Ibope completa essas informações através de um Levantamento Socioeconômico (LSE) próprio, que, além de pesquisar as características dos domicílios para definir a melhor estrutura amostral e a estimativa dos universos pesquisados, também oferece endereços para a composição do painel.

Dessa forma, o desenho amostral do painel é feito em duas fases. A primeira compreende a definição de domicílios que farão parte da pesquisa do LSE. A segunda fase consiste na escolha dos domicílios que efetivamente farão parte do painel, dentro da amostra de pesquisa pelo LSE. A partir dessa amostra é feita uma projeção estatística que aponta a audiência total de determinado programa ou canal no Brasil todo.

\section{Índices de audiência analisados}

Os índices de audiência para a presente pesquisa foram fornecidos pela $\mathrm{TV}$ Record, exportados e coletados a partir dos serviços contratados pela emissora junto ao Ibope. Para o presente estudo foram utilizados os seguintes dados referentes à medição da audiência na Grande São Paulo:

1. média diária da audiência prévia, das sete até meia-noite, do ano de 2012, das emissoras Record, Globo e SBT;

2. média diária da audiência consolidada, das sete até meia-noite, do ano de 2012, das emissoras Record, Globo e SBT;

3. audiência prévia, minuto a minuto, das sete até meia-noite, dos dias $1^{\circ}$ a 7 de novembro de 2012, das emissoras Record, Globo e SBT;

4. audiência consolidada, minuto a minuto, das sete até meia-noite, dos dias $1^{\circ}$ a 7 de novembro de 2012, das emissoras Record, Globo e SBT; 
5. audiência prévia, minuto a minuto, das sete até meia-noite, dos dias 10 a 16 de janeiro de 2013, das emissoras Record, Globo e SBT;

6. audiência consolidada, minuto a minuto, das sete até meia-noite, dos dias 10 a 16 de janeiro de 2013, das emissoras Record, Globo e SBT;

A semana compreendida entre os dias $1^{\circ}$ e 7 de novembro de 2012 foi escolhida em função do começo da presente pesquisa, que teve o início das atividades naquela semana. Já os dias 10 a 16 de janeiro foram escolhidos aleatoriamente, ainda no mês de novembro de 2012. Antes, portanto, de os índices de audiência dessa semana terem sido publicados.

\section{Índices de 2012}

Tv Record

\section{Tabela 1}

\section{Índices de audiência e respectivas variações durante 2012 da tv Record}

\begin{tabular}{|l|c|c|c|c|c|c|c|c|c|c|c|c|c|}
\hline \multicolumn{1}{|c|}{ Record } & 1 & 2 & 3 & 4 & 5 & 6 & 7 & 8 & 9 & 10 & 11 & 12 & Média \\
\hline Prévia Média & 6,86 & 6,76 & 6,58 & 6,69 & 6,28 & 6,23 & 5,93 & 5,97 & 5,59 & 5,49 & 6,47 & 5,60 & 6,20 \\
\hline Aud. Média & 6,79 & 6,76 & 6,57 & 6,69 & 6,33 & 6,21 & 5,98 & 6,01 & 5,57 & 5,44 & 6,34 & 5,57 & 6,19 \\
\hline Variação \% & $-1,05$ & 0,02 & $-0,11$ & 0,08 & 0,83 & $-0,28$ & 0,70 & 0,56 & $-0,35$ & $-0,73$ & $-2,13$ & $-0,39$ & $-0,24$ \\
\hline Var. Neg & 19 & 16 & 12 & 14 & 11 & 15 & 7 & 11 & 16 & 17 & 25 & 19 & 15,17 \\
\hline Var. Pos & 12 & 13 & 19 & 16 & 20 & 15 & 24 & 20 & 14 & 14 & 5 & 12 & 15,33 \\
\hline Freq. =0 & 0 & 0 & 0 & 0 & 0 & 0 & 0 & 0 & 0 & 0 & 0 & 0 & 0,00 \\
\hline Var. Máxima & 0,29 & 0,25 & 0,23 & 0,33 & 0,26 & 0,19 & 0,18 & 0,22 & 0,21 & 0,14 & 0,17 & 0,25 & 0,23 \\
\hline Var. Média & $-0,08$ & $-0,00$ & $-0,00$ & 0,00 & 0,05 & $-0,02$ & 0,04 & 0,03 & $-0,02$ & $-0,05$ & $-0,14$ & $-0,02$ & $-0,02$ \\
\hline Var. Mínima & $-0,46$ & $-0,19$ & $-0,20$ & $-0,30$ & $-0,19$ & $-0,33$ & $-0,17$ & $-0,34$ & $-0,22$ & $-0,30$ & $-0,43$ & $-0,25$ & $-0,28$ \\
\hline
\end{tabular}

Verifica-se que em 2012 a TV Record teve uma média da audiência prévia de 6,20 pontos e consolidada de 6,19 pontos. Isso representa uma oscilação negativa de 0,01 ponto, ou na média do ano, os programas tiveram uma audiência $0,24 \%$ menor de do que a apontada pela prévia.

Durante esse período, a emissora registrou oscilações negativas (audiência consolidada menor do que a prévia) em 182 dias. Em outros 184 dias, as variações foram positivas. Considerando a média mensal, em cinco meses a variação foi positiva (fevereiro, abril, maio, julho e agosto) e nega- 
tiva nos outros sete meses (janeiro, março, junho, setembro, outubro, novembro e dezembro).

Por mês, em média 15,17 dias variaram negativamente e 13,33 positivamente. No mês de novembro, a variação foi negativa em 25 dias e positiva nos outros cinco. Foi o mês com maior impacto quantitativo diário na variação negativa do ano. Na média do mês, a audiência consolidada foi $2,13 \%$ menor do que a prévia, o que representa 0,14 pontos.

O mês de julho apresentou o maior impacto quantitativo diário na variação positiva, com 24 dias. Sete dias do mês variaram negativamente. Apesar disso, a audiência consolidada foi de apenas $0,70 \%$ maior do que a prévia, o que representa 0,04 pontos.

Analisando as médias mensais, é perceptível uma mudança no comportamento dos dados nos últimos quatro meses do ano, que oscilaram todos negativamente, sendo setembro, $-0,35 \%$; outubro, $-0,73 \%$; novembro, $-2,13 \%$; dezembro, $-0,39 \%$.

Considerando a média diária, a maior variação positiva aconteceu no mês de abril, com 0,33; a maior variação negativa foi em janeiro, com -0,46. Essa oscilação pode ser conferida visualmente na Figura 1.

\section{Figura 1}

\section{Variação mensal máxima, média e mínima dos índices de audiência consolidada em relação à prévia da tv Record}

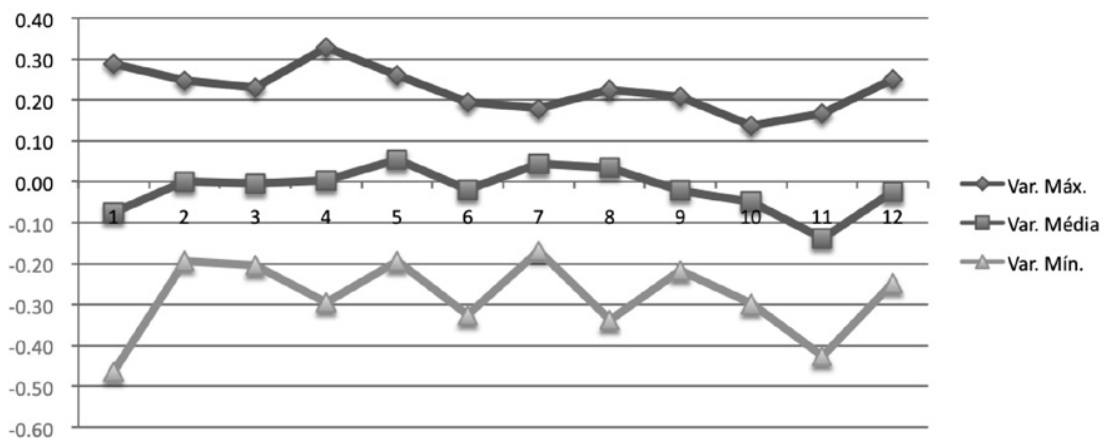


TV Globo

Tabela 2

\section{Índices de audiência e respectivas variações durante 2012 da tv Globo}

\begin{tabular}{|c|c|c|c|c|c|c|c|c|c|c|c|c|c|}
\hline Globo & 1 & 2 & 3 & 4 & 5 & 6 & 7 & 8 & 9 & 10 & 11 & 12 & Média \\
\hline $\begin{array}{c}\text { Prévia } \\
\text { Média }\end{array}$ & 15,72 & 14,41 & 14,99 & 14,65 & 15,37 & 16,09 & 15,33 & 14,86 & 14,62 & 14,55 & 13,32 & 12,84 & 14,73 \\
\hline Aud. Média & 15,56 & 14,39 & 14,95 & 14,69 & 15,45 & 16,10 & 15,35 & 14,97 & 14,55 & 14,55 & 13,41 & 12,87 & 14,74 \\
\hline Variação \% & $-0,94$ & $-0,15$ & $-0,32$ & 0,28 & 0,50 & 0,05 & 0,14 & 0,75 & $-0,50$ & 0,00 & 0,67 & 0,29 & 0,06 \\
\hline Var. Neg & 24 & 14 & 17 & 12 & 10 & 13 & 15 & 9 & 18 & 17 & 9 & 15 & 14,42 \\
\hline Var. Pos & 7 & 15 & 14 & 18 & 21 & 17 & 15 & 22 & 12 & 14 & 21 & 16 & 16,00 \\
\hline Freq. $=0$ & 0 & 0 & 0 & 0 & 0 & 0 & 1 & 0 & 0 & 0 & 0 & 0 & 0,08 \\
\hline Var. Máxima & 0,22 & 0,34 & 0,49 & 0,31 & 0,42 & 0,32 & 0,38 & 0,33 & 0,40 & 0,67 & 0,51 & 0,46 & 0,40 \\
\hline Var. Média & $-0,16$ & $-0,01$ & $-0,05$ & 0,05 & 0,08 & 0,01 & 0,02 & 0,11 & $-0,07$ & 0,00 & 0,09 & 0,03 & 0,01 \\
\hline Var. Mínima & $-0,65$ & $-0,42$ & $-0,63$ & $-0,29$ & $-0,37$ & $-0,42$ & $-0,28$ & $-0,28$ & $-0,51$ & $-0,36$ & $-0,34$ & $-0,48$ & $-0,42$ \\
\hline
\end{tabular}

A TV Globo registrou em 2012 uma audiência prévia média de 14,73 e consolidada de 14,74 , uma oscilação positiva de $0,06 \%$, ou 0,01 ponto. Durante o ano, foram 173 dias com oscilações negativas e 192 positivas. Nas médias mensais, foram quatro meses com variação média negativa (janeiro, fevereiro, março e setembro) e oito variações positivas (abril, maio, junho, julho, agosto, outubro, novembro e dezembro). O mês de outubro representou uma variação positiva de 0,003 pontos, o que se aproxima de zero no arredondamento.

Por mês, em média 14,42 dias variaram negativamente e 16, positivamente. A maior variação positiva aconteceu no mês de outubro, com 0,67 ; enquanto a maior variação negativa foi em janeiro, com -0,65.

No mês de janeiro, a variação foi negativa em 24 dias e positiva nos outros sete. Foi o mês com maior impacto quantitativo diário na variação negativa do ano. Na média do mês, a audiência consolidada foi $0,94 \%$ menor do que a prévia ou 0,16 pontos.

O mês de agosto teve o maior impacto quantitativo diário na variação positiva, com 22 dias. Nove dias do mês variaram negativamente. A audiência consolidada foi $0,75 \%$ maior do que a prévia, o que representa 0,11 pontos. 
A TV Globo, que começou oscilando negativamente nos três primeiros meses do ano (janeiro, -0,16; fevereiro, -0,01 e março, -0,05), praticamente se estabilizou ao longo dos demais nove meses. Oscilou negativamente apenas em setembro $(-0,07)$. A variação da média mensal positiva também não é muito significante e oscila entre 0,003 (outubro) a 0,11 (agosto).

Considerando a média diária, a maior variação positiva aconteceu no mês de agosto, com 0,11 ; a maior variação negativa foi em janeiro, com $-0,65$ pontos. Essa oscilação pode ser conferida visualmente na Figura 2.

\section{Figura 2}

\section{Variação mensal máxima, média e mínima dos índices de audiência consolidada em relação à prévia da tv Globo}

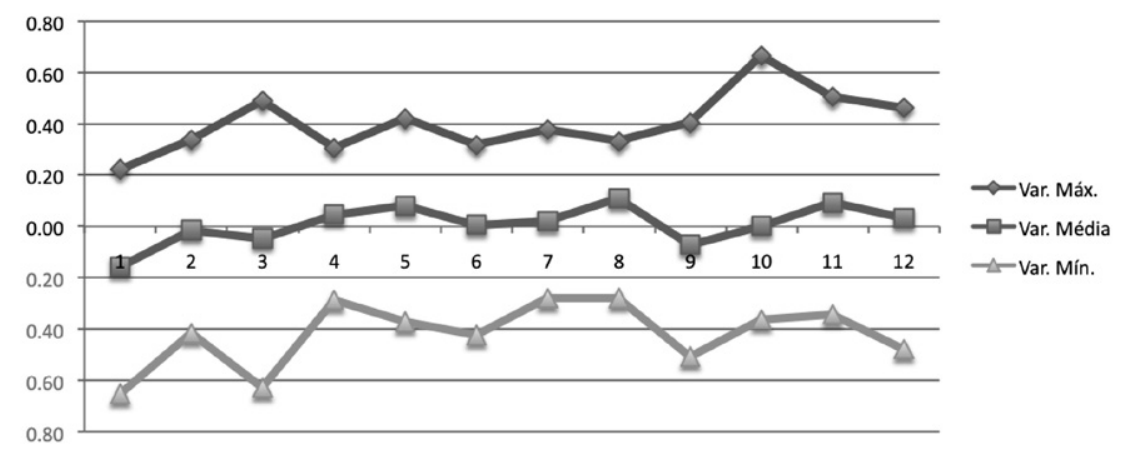

SBT

\section{Tabela 3}

\section{Índices de audiência e respectivas variações durante 2012 do SBT}

\begin{tabular}{|c|c|c|c|c|c|c|c|c|c|c|c|c|c|}
\hline SBT & 1 & 2 & 3 & 4 & 5 & 6 & 7 & 8 & 9 & 10 & 11 & 12 & Média \\
\hline Prévia Média & 5,40 & 4,82 & 4,96 & 4,94 & 5,41 & 6,20 & 6,10 & 5,56 & 5,46 & 5,71 & 6,32 & 5,57 & 5,54 \\
\hline Aud. Média & 5,40 & 4,97 & 5,12 & 5,14 & 5,68 & 6,25 & 6,08 & 5,50 & 5,42 & 5,71 & 6,30 & 5,56 & 5,59 \\
\hline Variação \% & 0,05 & 3,14 & 3,19 & 4,16 & 5,18 & 0,82 & $-0,29$ & $-1,03$ & $-0,64$ & 0,06 & $-0,37$ & $-0,35$ & 1,16 \\
\hline Var. Neg & 13 & 3 & 2 & 3 & 0 & 12 & 17 & 22 & 21 & 15 & 15 & 19 & 11,83 \\
\hline Var. Pos & 18 & 26 & 29 & 27 & 31 & 18 & 14 & 9 & 9 & 16 & 15 & 12 & 18,67 \\
\hline Freq. $=0$ & 0 & 0 & 0 & 0 & 0 & 0 & 0 & 0 & 0 & 0 & 0 & 0 & 0,00 \\
\hline Var. Máxima & 0,26 & 0,38 & 0,34 & 0,41 & 0,64 & 0,39 & 0,16 & 0,14 & 0,11 & 0,18 & 0,16 & 0,25 & 0,28 \\
\hline Var. Média & 0,00 & 0,15 & 0,16 & 0,20 & 0,28 & 0,05 & $-0,02$ & $-0,05$ & $-0,04$ & $-0,00$ & $-0,02$ & $-0,02$ & 0,06 \\
\hline Var. Mínima & $-0,35$ & $-0,10$ & $-0,09$ & $-0,15$ & 0,03 & $-0,43$ & $-0,19$ & $-0,32$ & $-0,39$ & $-0,25$ & $-0,29$ & $-0,22$ & $-0,23$ \\
\hline
\end{tabular}


O sBT registrou em 2012 uma audiência prévia média de 5,54 e consolidada de 5,59, o que corresponde a uma oscilação positiva de $1,16 \%$, ou 0,28 pontos na média do ano. Durante o período, foram 142 dias com oscilações negativas e 224 positivas. Considerando a média mensal, todo o primeiro semestre teve variação positiva, enquanto todo o segundo semestre registrou variação negativa (o mês de outubro, que no arrendamento ficou sem variação, oscilou - 0,00003 pontos). Durante o primeiro semestre, o SBT registrou apenas 33 dias com variação negativa, contra 149 positivas. No segundo semestre, houve uma inversão, com 109 variações negativas e 75 positivas.

Por mês, em média 11,83 dias variaram negativamente e 18,67 positivamente. No mês de agosto, a variação foi negativa em 22 dias e positiva nos outros nove. Foi o mês com maior impacto quantitativo diário na variação negativa do ano. Na média do mês, a audiência consolidada foi 1,03\% menor do que a prévia ou 0,05 pontos.

O mês de maio teve o maior impacto quantitativo diário na variação positiva, com todos os dias do mês variando positivamente. Nesse mês, a audiência consolidada foi $5,18 \%$ maior do que a prévia, o que representa 0,28 pontos.

Considerando a média diária, a maior variação positiva aconteceu no mês de maio, com 0,64; a maior variação negativa foi em junho, com -0,43. Essa oscilação pode ser conferida visualmente na Figura 3.

\section{Figura 3}

\section{Variação mensal máxima, média e mínima dos índices de audiência consolidada em relação à prévia do SBT}

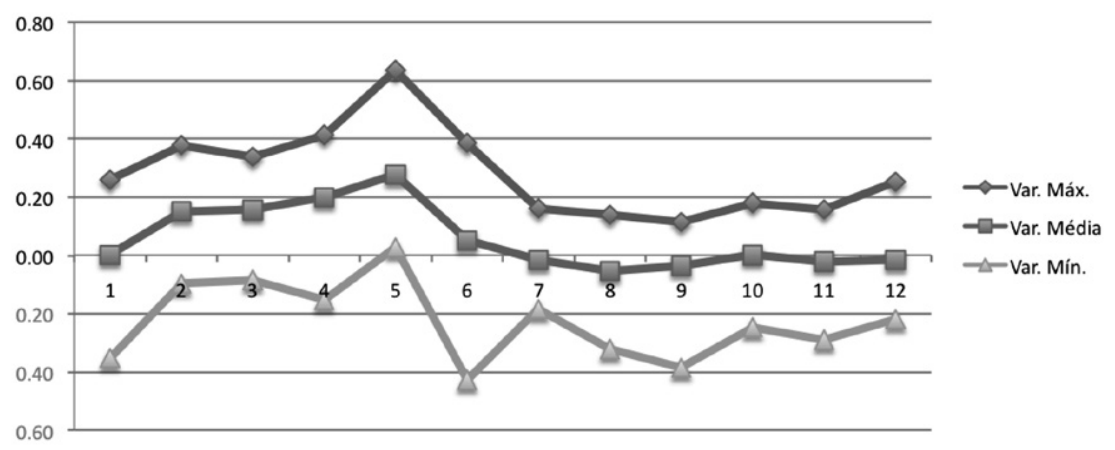




\section{Análise comparativa}

Considerando as três emissoras, há variações mensais diferentes: quatro meses variaram negativamente e oito positivamente na TV Globo; cinco variações positivas e sete negativas na TV Record; seis variações positivas e seis negativas no SBT.

As tendências do SBT e Record mostram uma mudança considerável no comportamento dos dados. Enquanto o SBT teve uma variação bastante positiva em todos os meses do primeiro semestre, no segundo oscilou negativamente. Deve se atentar para a inversão total dessa variação, que foi extremamente positiva no primeiro semestre e totalmente negativa no segundo.

No caso da Record, chama a atenção o fato de os últimos quatro meses do ano terem oscilado negativamente, similar ao que aconteceu com a TV Globo nos três primeiros meses do ano. Na média anual, a Record foi a única emissora com oscilação negativa.

Em nenhum mês as três emissoras variaram negativamente. Por outro lado, nos meses de abril e maio as três emissoras analisadas variaram positivamente.

Analisando o gráfico com os valores absolutos (em pontos) da variação da audiência consolidada em relação à prévia (Figura 4), percebe-se uma oscilação maior do SBT (representada principalmente pelo primeiro semestre atípico), seguido da TV Globo e da Record. A variação da Record está mais próxima do eixo $\mathrm{X}$, ou seja, do zero. Essa menor variação também pode ser percebida pelo desvio padrão ${ }^{4}$ da variação de dados da Record, que é de 0,05 . A Globo, com uma variação um pouco maior, tem desvio padrão na média mensal durante o ano de 2012 de 0,07; o SBT, de 0,11.

4 O desvio padrão de uma amostra caracteriza a dispersão dos dados em torno da média ou, em outras palavras, o quanto um conjunto de dados se aproxima da média. Um desvio padrão baixo significa que os dados se aglomeram perto da média, enquanto um número alto do desvio padrão caracteriza uma distribuição de dados distantes da média ou uma maior oscilação (Mattar, 2007). 


\section{Figura 4}

\section{Variação em pontos da audiência consolidada em relação à prévia}

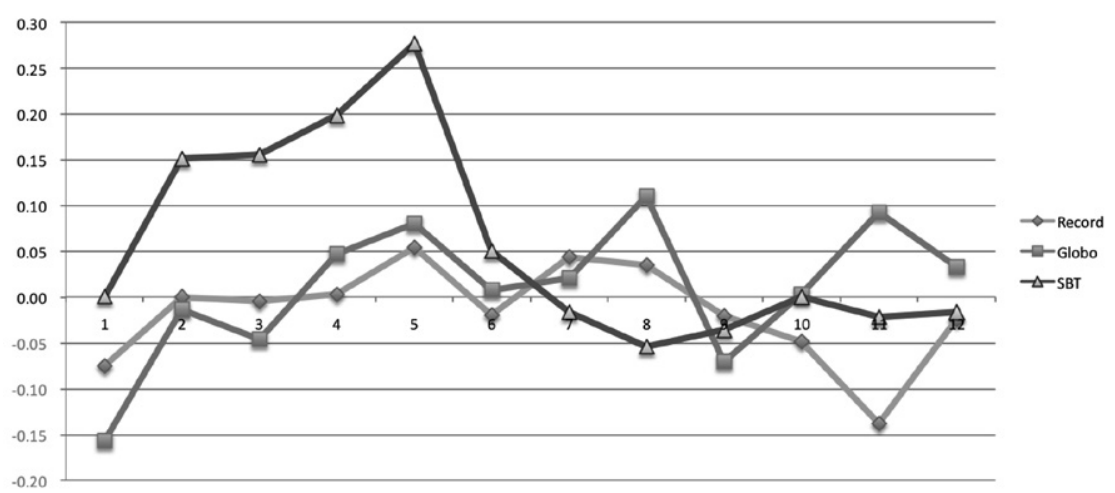

Porém, se considerarmos as variações relativas de acordo com os índices de audiência, ou seja, em percentual, as curvas da TV Globo e Record tem comportamentos semelhantes, muito próximos (Figura 5). A única variação significativa ocorreu no mês de novembro, que pode ser considerada como totalmente fora do padrão para a TV Record. Apesar de a Globo ter variação absoluta maior, percentualmente ela é muito similar à Record.

O SBT mantém a mesma curva, tanto nos valores absolutos quanto nos relativos.

\section{Figura 5 \\ Variação percentual da audiência consolidada em relação à prévia}

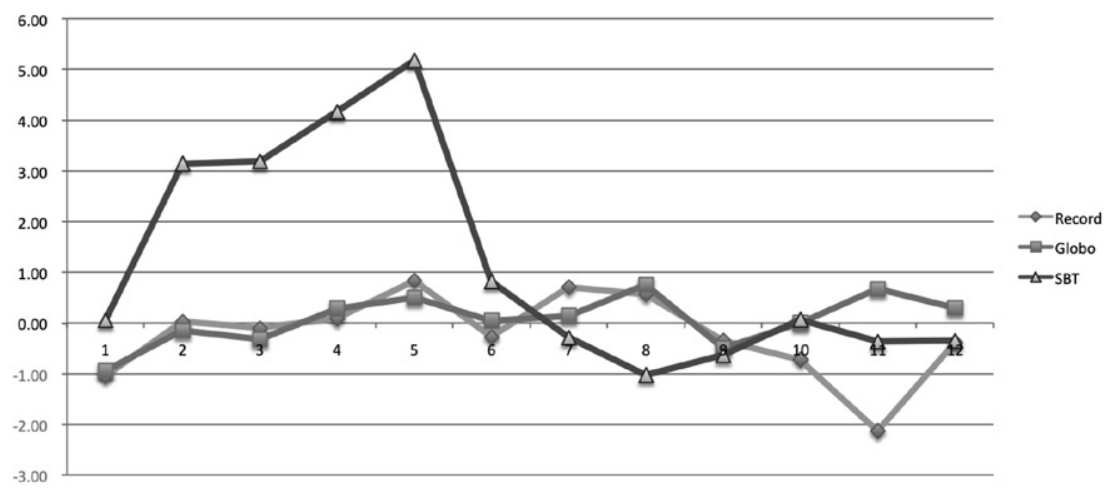




\section{Análise da primeira semana de novembro}

Considerando a necessidade dos Departamentos de Programação das emissoras de TV de disporem de dados confiáveis em tempo real sobre o comportamento da audiência, fez-se uma análise detalhada desses índices acompanhando a evolução prévia e consolidada durante o dia. No caso da programação ao vivo, enquanto o programa está no ar, os dados da audiência minuto a minuto são mais importantes para os departamentos de programação do que os consolidados.

Através da análise da média diária e mensal é possível perceber que há variações, geralmente pequenas. No entanto, analisando a diferença entre os dados consolidados e os fornecidos minuto a minuto pelo Ibope, notam-se variações significativamente maiores, o que afeta a visão estratégica da tomada de decisões.

Para tanto, foram analisados os índices de audiência da TV Record, SBT e Globo no período de $1^{\circ}$ a 7 de novembro de 2012, comparando as variações dos dados da audiência prévia com a consolidada. Foi considerado o horário das 7 h00 até as $23 \mathrm{~h} 59$, que totalizam 17 horas, ou $1.020 \mathrm{mi}$ nutos por dia.

Atentando especificamente para a variação da audiência consolidada para a prévia nos dados minutos a minuto, que são as informações mais importantes no dia a dia da programação, percebem-se comportamentos diferentes entre as três emissoras. A Record apresentou uma variação negativa em seis dos sete dias analisados; o SBT teve variação positiva em cinco dos sete dias; a Globo teve variação positiva em seis dos sete dias. O desempenho entre Record e Globo foi exatamente o oposto, inclusive nos dias. A variação positiva de uma emissora corresponde à variação negativa da outra.

\section{Análise dos dados na semana}

No período de $1^{\circ}$ a 7 de novembro, a TV Record registrou a seguinte audiência prévia e consolidada, com as respectivas variações: 


\section{Tabela 4}

\section{Audiência da Record no período de $1^{0}$ a 7 de novembro, com as respectivas variações}

\begin{tabular}{|c|c|c|c|c|c|c|c|}
\hline RECORD & 1 & 2 & 3 & 4 & 5 & 6 & 7 \\
\hline Prévia Média & 6,05 & 5,87 & 7,12 & 6,82 & 6,35 & 5,84 & 5,99 \\
\hline Aud. Média & 5,72 & 5,75 & 7,00 & 6,97 & 6,15 & 5,63 & 5,88 \\
\hline Variação Média \% & $-5,70$ & $-2,26$ & $-1,64$ & 1,44 & $-3,42$ & $-3,89$ & $-1,81$ \\
\hline Var. Neg & 816 & 702 & 671 & 359 & 736 & 750 & 693 \\
\hline Var. Pos & 203 & 317 & 349 & 660 & 283 & 269 & 326 \\
\hline Freq. =0 & 1 & 1 & 0 & 1 & 1 & 1 & 1 \\
\hline Var. Máxima & 0,82 & 0,89 & 1,39 & 1,21 & 1,75 & 0,97 & 1,19 \\
\hline Var. Média & $-0,33$ & $-0,12$ & $-0,12$ & 0,15 & $-0,21$ & $-0,21$ & $-0,10$ \\
\hline Var. Mínima & $-1,28$ & $-1,13$ & $-1,40$ & $-0,70$ & $-1,42$ & $-1,00$ & $-0,84$ \\
\hline
\end{tabular}

\section{Figura 6}

\section{Variações positivas e negativas da tv Record do período}

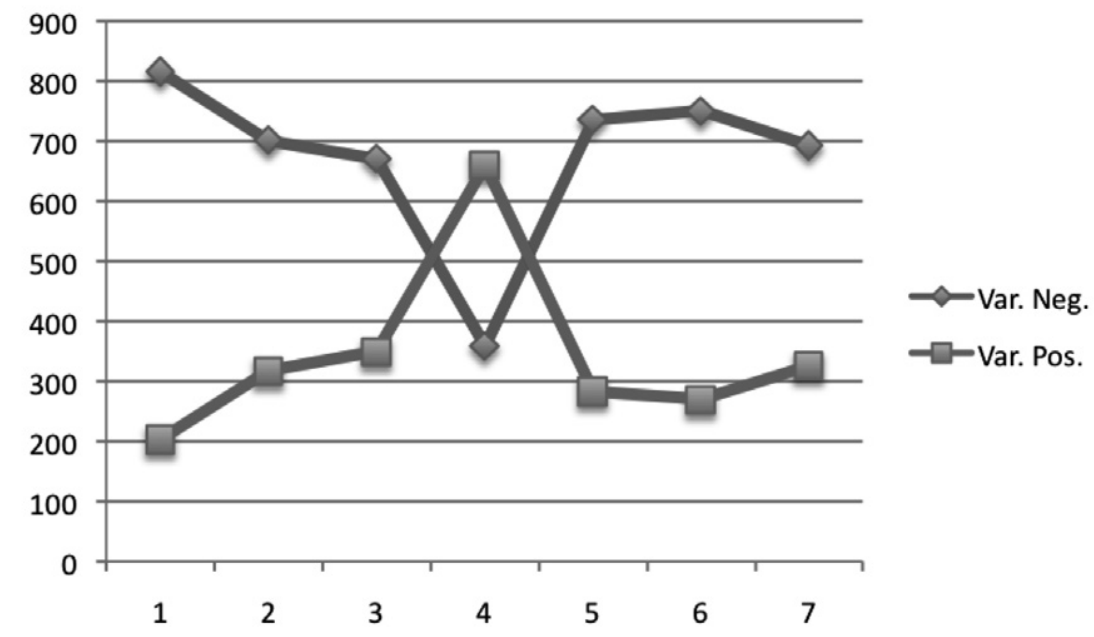

Observa-se que houve uma série de variações ao longo da semana. A medição prévia, em tempo real, oscilou entre 5,84 a 7,12; a audiência consolidada oscilou entre 5,63 a 7 pontos. No entanto, o que deve ser analisado com mais cuidado é a variação da audiência prévia para a consolidada no mesmo dia. Nesse ponto, percebe-se praticamente uma regra: todos os minutos no dia variaram, à exceção de um único minuto no dia, no qual ambas as medições foram equivalentes. Nos demais minutos e dias, predominaram 
as variações negativas, ou seja, a audiência consolidada foi menor do que a prévia. A Figura 6 compara quantos minutos por dia oscilaram positivamente e quantos tiverem variações negativas durante a semana analisada.

É predominante a variação negativa ao longo da semana. Apenas em um dia, 4 de novembro, a variação da prévia para a consolidada foi positiva, ou seja, a audiência consolidada foi maior do que a medição prévia.

A Figura 7 dimensiona em pontos o tamanho dessas variações. Quando a variação foi positiva durante a semana, (Var. Máx. no gráfico) oscilou entre as máximas de 0,82 no dia $1^{\circ}$ de novembro a 1,75 pontos no dia 5 de novembro. Quanto às variações negativas (Var. Mín. no gráfico), a máxima oscilou entre $-1,42$ a $-0,7$ pontos. A média na semana ficou entre - 0,33 $(-5,71 \%)$ e 0,15 pontos $(1,45 \%)$, com seis variações negativas.

\section{Figura 7 \\ Variações máxima, média e mínima do período}

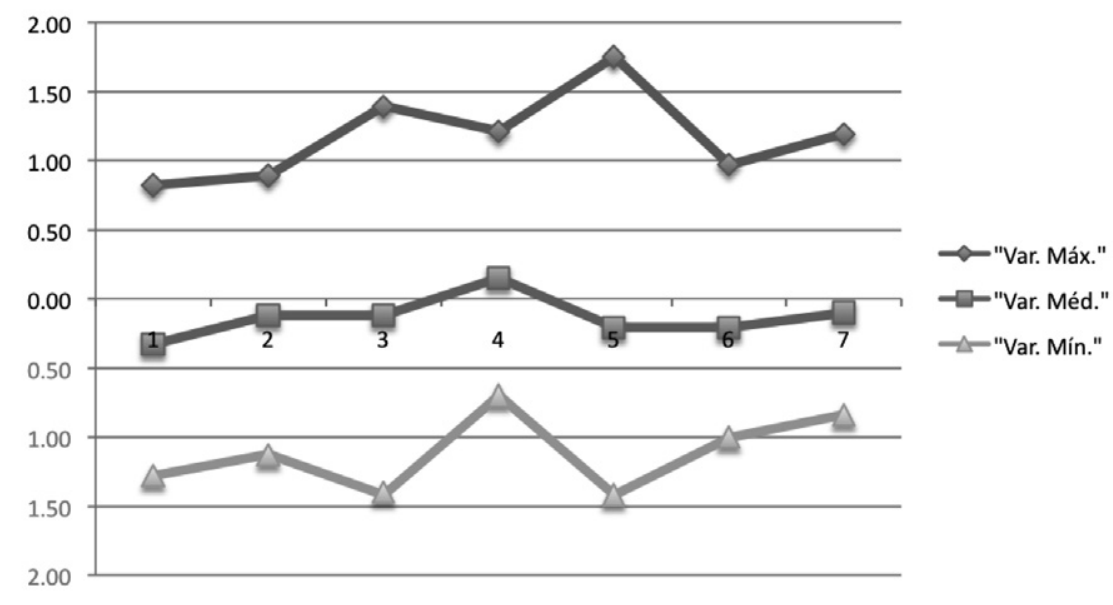

Durante o período, a variação negativa foi mais uniforme do que a positiva e oscilou menos. À exceção do dia 4, único com variação final positiva, e do dia 7, cuja variação máxima negativa foi de -0,84, a variação negativa máxima se concentrou entre - 1 e -1,42. Enquanto a variação positiva está mais distribuída, com três resultados na casa dos 0,5 a 1 , outros três entre 1 e 1,5 e um resultado acima de 1,5. Essa oscilação também pode ser 
percebida pela média da variação máxima positiva, de 1,17 e negativa, de $-1,11$. Já o desvio padrão ficou em 0,32 e 0,28 , respectivamente.

No mesmo período, o SBT registrou a seguinte audiência prévia e consolidada, com as respectivas variações:

\section{Tabela 5}

\section{Audiência do SBT no período de $1^{\circ}$ a 7 de novembro, com as respectivas variações}

\begin{tabular}{|c|c|c|c|c|c|c|c|}
\hline SBT & 1 & 2 & 3 & 4 & 5 & 6 & 7 \\
\hline Prévia Média & 5,39 & 6,57 & 5,21 & 7,67 & 5,61 & 5,68 & 6,06 \\
\hline Aud. Média & 5,50 & 6,63 & 5,22 & 7,82 & 5,46 & 5,73 & 6,03 \\
\hline Variação Média \% & 2,14 & 1,58 & 0,38 & 2,04 & $-2,39$ & 1,05 & $-0,54$ \\
\hline Var. Neg & 372 & 426 & 520 & 348 & 699 & 467 & 523 \\
\hline Var. Pos & 648 & 594 & 499 & 668 & 320 & 551 & 496 \\
\hline Freq. $=0$ & 0 & 0 & 1 & 4 & 1 & 2 & 1 \\
\hline Var. Máxima & 1,26 & 1,66 & 1,06 & 1,38 & 0,83 & 1,38 & 1,50 \\
\hline Var. Média & 0,10 & 0,06 & 0,01 & 0,15 & $-0,15$ & 0,06 & $-0,03$ \\
\hline Var. Mínima & $-0,86$ & $-0,89$ & $-0,99$ & $-0,77$ & $-1,47$ & $-0,96$ & $-1,07$ \\
\hline
\end{tabular}

Figura 8

\section{Variações positivas e negativas do SBT no período}

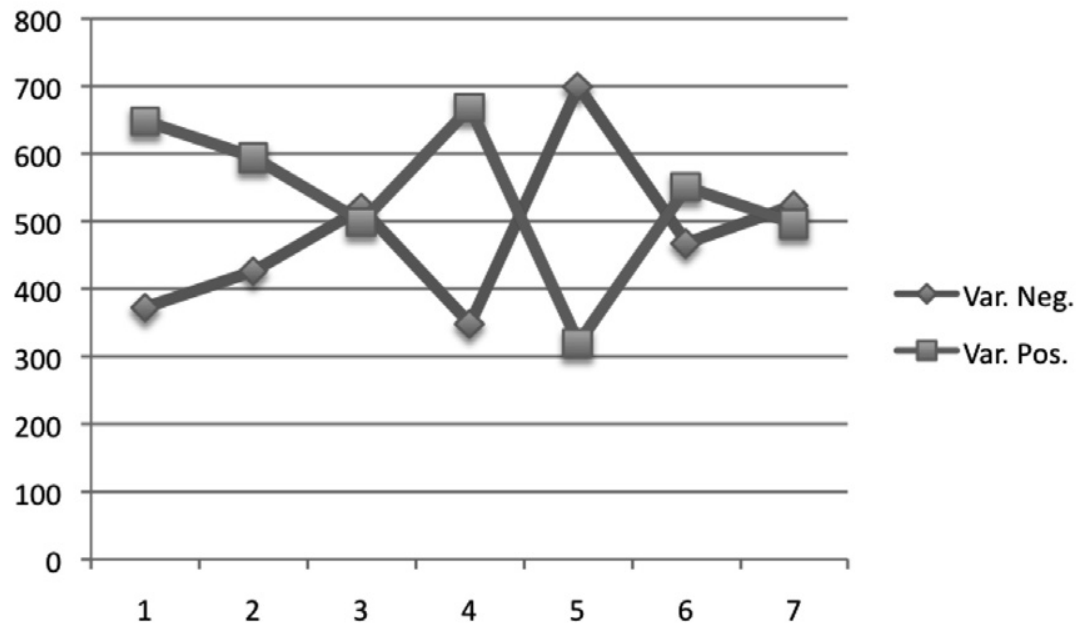

No caso do SBT observa-se um comportamento dos dados diferente da Record, com duas variações negativas e cinco positivas. A medição prévia, 
em tempo real, oscilou entre 5,21 a 7,67; a audiência consolidada oscilou entre 5,22 a 7,82 pontos. No caso da variação entre a prévia e a consolidada minuto a minuto, pode-se afirmar que o SBT também segue a mesma regra da Record, com poucas exceções. Ao longo da semana, todos os minutos variaram, com exceções que oscilaram entre um e quatro minutos.

Nos demais minutos, ao contrário da TV Record, na qual predominou a variação negativa entre a audiência prévia e a consolidada, com o SBT predominam as variações positivas, mas com pequena diferença. No dia 5 a variação foi negativa tanto nos pontos quanto na quantidade de minutos. Já no dia três, a audiência consolidada foi 0,01 ponto maior do que a prévia. No entanto, durante o dia, 520 minutos tiveram variação negativa, contra 499 variações positivas. A Figura 8 compara quantos minutos por dia oscilaram positivamente e quantos tiveram variações negativas durante a semana analisada.

A Figura 9 dimensiona em pontos o tamanho dessas variações. Quando a variação foi positiva durante a semana, oscilou entre as máximas de 0,83 no dia 5 de novembro a 1,66 pontos no dia 2 de novembro. Já quanto às variações negativas, a máxima oscilou entre $-1,47$ a $-0,77$ pontos. A média na semana ficou entre $-0,15(-2,39 \%)$ e 0,15 pontos $(2,14 \%)$, com cinco variações positivas.

\section{Figura 9}

Variações máxima, média e mínima do período

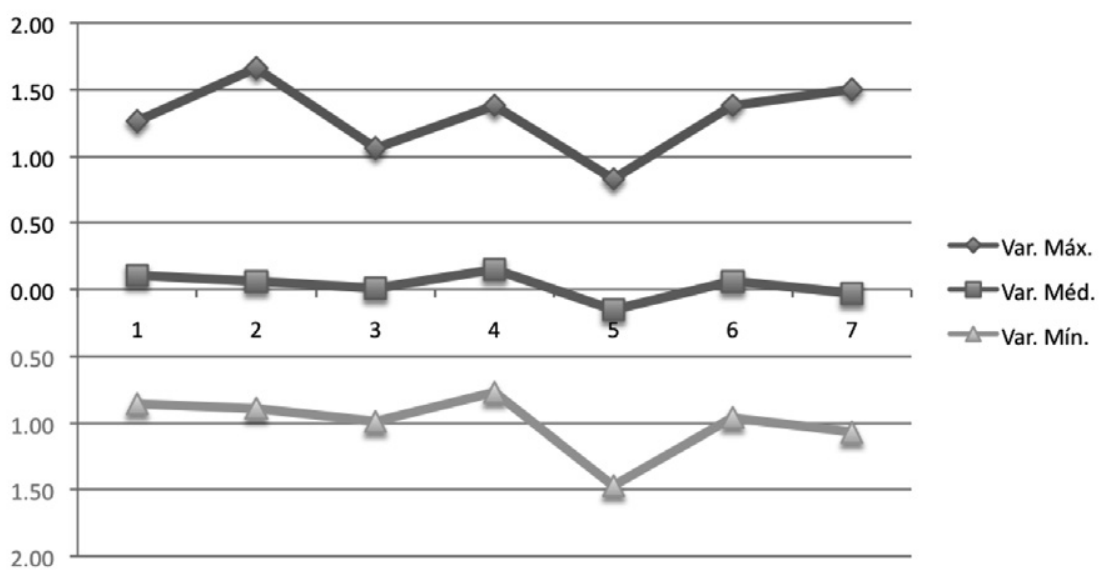


No período a variação negativa oscilou mais próxima da média, com a maioria dos dados na casa dos 0,5 a 1,0. Já na variação positiva predominaram os valores na casa do 1,0 a 1,5. Um dado a ser ressaltado é a variação média, que oscilou pouco, sempre perto do zero. Essa oscilação também pode ser percebida pela média da variação máxima positiva, de 1,30, e negativa, de -1,0. O desvio padrão, por sua vez, ficou em 0,28 e 0,23, respectivamente.

A Tv Globo registrou a seguinte audiência prévia e consolidada, com as respectivas variações:

\section{Tabela 6}

\section{Audiência da Globo no período de $1^{0}$ a 7 de novembro, com as respectivas variações}

\begin{tabular}{|c|c|c|c|c|c|c|c|}
\hline GLOBO & 1 & 2 & 3 & 4 & 5 & 6 & 7 \\
\hline Prévia Média & 13,21 & 13,15 & 12,77 & 13,48 & 14,33 & 12,60 & 12,65 \\
\hline Aud. Média & 13,55 & 13,71 & 13,06 & 13,41 & 14,50 & 12,74 & 12,76 \\
\hline Variação Média \% & 2,66 & 3,38 & 1,50 & 0,25 & $-0,01$ & 1,43 & 1,16 \\
\hline Var. Neg & 269 & 244 & 304 & 539 & 465 & 417 & 400 \\
\hline Var. Pos & 751 & 776 & 716 & 480 & 554 & 603 & 620 \\
\hline Freq. $=0$ & 0 & 0 & 0 & 1 & 1 & 0 & 0 \\
\hline Var. Máxima & 2,29 & 2,53 & 2,80 & 1,26 & 2,78 & 2,16 & 2,22 \\
\hline Var. Média & 0,34 & 0,55 & 0,29 & $-0,08$ & 0,17 & 0,15 & 0,12 \\
\hline Var. Mínima & $-1,24$ & $-0,68$ & $-1,39$ & $-1,56$ & $-1,41$ & $-1,42$ & $-1,44$ \\
\hline
\end{tabular}

Figura 10

\section{Variações positivas e negativas da tv Globo no período}

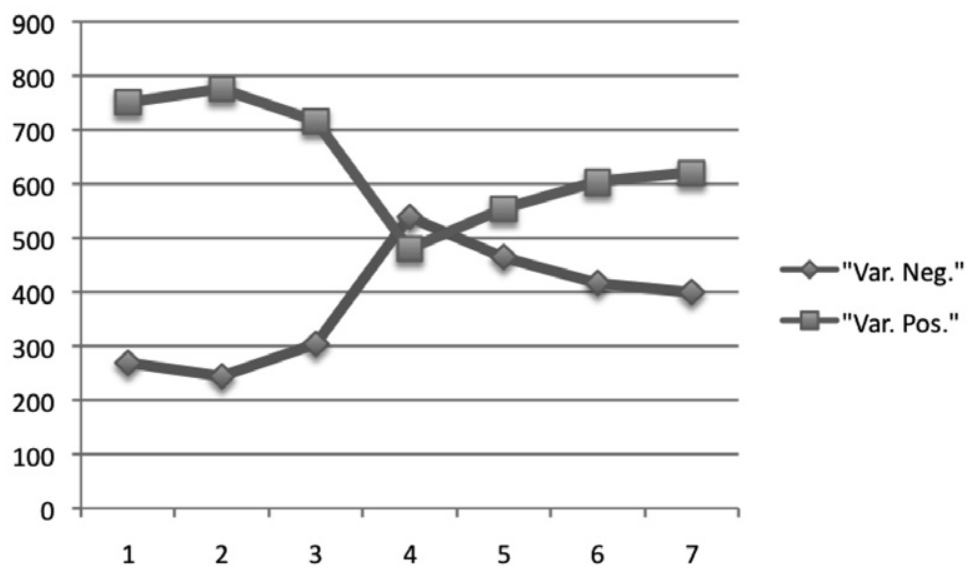


No caso da TV Globo observa-se um comportamento peculiar na variação dos dados da audiência prévia em relação à consolidada. Ao contrário da Record, com apenas uma variação positiva no período, a TV Globo apresentou seis variações positivas e apenas uma, bastante pequena, negativa. A medição prévia, em tempo real, oscilou entre 12,60 a 14,33; a audiência consolidada oscilou entre 12,74 a 14,50 pontos no período em análise.

Similar ao que aconteceu com SBT e Record, praticamente todos os minutos no dia tiveram variações. $\mathrm{Na}$ Globo predominam substancialmente as variações positivas. Ou seja, a audiência consolidada foi superior à prévia, com média na semana de 0,22 pontos, ou $1,48 \%$. São números consideráveis em comparação aos do SBT $(0,03$ e 0,61\%, respectivamente) e da Record (-0,13 e $-2,47 \%$, respectivamente).

A Figura 10 dimensiona em pontos o tamanho da variação ao longo da semana. Em comparação à Record, no mesmo dia em que a emissora teve a única variação positiva da audiência consolidada em relação à prévia, a Globo teve a única variação negativa.

\section{Figura 11 \\ Variações máxima, média e mínima do período}

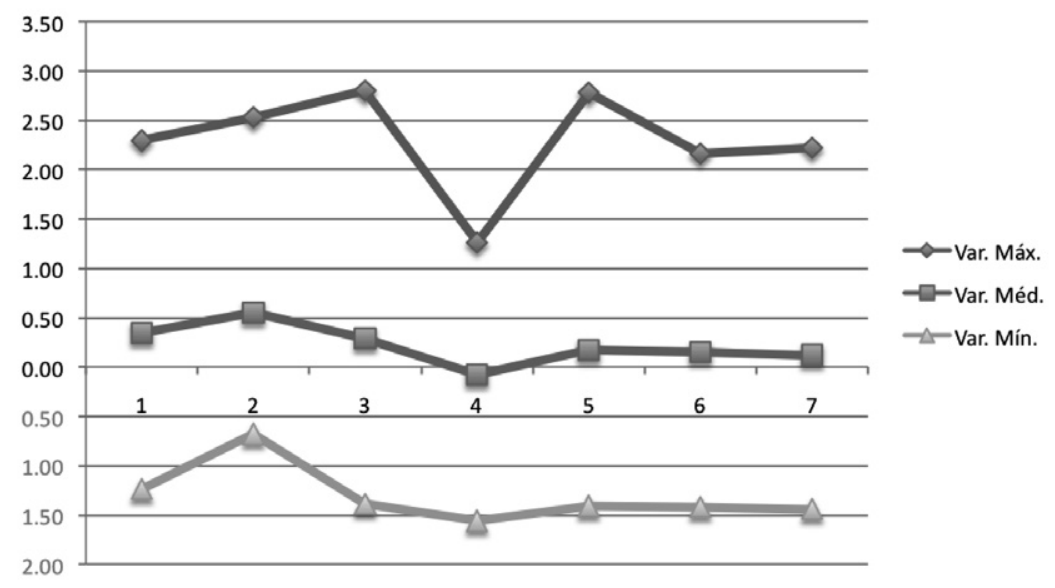

Durante o período, a variação negativa foi mais uniforme do que a positiva. Durante seis dias, a variação negativa se aproximou do -1,5. Chama a atenção a variação positiva, que oscilou longe do zero. Em três dias 
ficou acima de 2,50 pontos, com máxima de 2,80 dia 3 de novembro; em outros três ficou entre 2,0 e 2,50, algo não identificado nos demais canais, que não tiveram nenhuma variação positiva acima de $2,0 . \mathrm{O}$ desvio padrão da variação máxima foi de 0,52 e da mínima de 0,29.

Para efeitos de comparação, analisaram-se também os índices de audiência das três emissoras no período de 10 a 16 de janeiro de 2013. Esse período foi definido aleatoriamente antes do dia 10 de janeiro desse ano, o que evitou, dessa forma, o conhecimento prévio dos dados. O objetivo da análise desse período é a comparação das variações com a primeira semana de novembro de 2012, que buscou identificar se elas se mantinham.

A tabela a seguir apresenta a audiência prévia e consolidada do período.

\section{Tabela 7 \\ Média diária das audiências do período de 10 a 16 de janeiro de 2013}

\begin{tabular}{|c|c|c|c|c|c|c|c|c|c|}
\hline Dia & \multicolumn{4}{|c|}{ Record } & \multicolumn{3}{c|}{ Globo } & \multicolumn{3}{c|}{ SBT } \\
\hline & Prévia & Consolidada & Diferença & Previa & Consolidada & Diferença & Prévia & Consolidada & Diferença \\
\hline 10 & 5,6 & 5,7 & 0,1 & 14,8 & 14,9 & 0,1 & 6,2 & 6,1 & $-0,1$ \\
\hline 11 & 4,9 & 4,9 & 0,0 & 14,7 & 14,0 & $-0,7$ & 5,5 & 5,5 & $-0,0$ \\
\hline 12 & 5,8 & 5,6 & $-0,2$ & 12,7 & 12,6 & $-0,1$ & 4,6 & 4,6 & 0,0 \\
\hline 13 & 6,1 & 6,2 & 0,1 & 11,8 & 11,5 & $-0,3$ & 6,2 & 6,1 & $-0,1$ \\
\hline 14 & 5,4 & 5,4 & $-0,0$ & 14,7 & 14,5 & $-0,2$ & 5,6 & 5,3 & $-0,3$ \\
\hline 15 & 5,6 & 5,5 & $-0,1$ & 15,3 & 15,1 & $-0,2$ & 5,5 & 5,5 & $-0,0$ \\
\hline 16 & 5,6 & 5,6 & 0,0 & 14,9 & 15,0 & 0,1 & 5,3 & 5,3 & 0,0 \\
\hline
\end{tabular}

A Figura 12 mostra as diferenças entre a audiência prévia e a consolidada, e a evolução ao longo da semana nas três emissoras. 
Figura 12

Diferenças entre audiência prévia e consolidada

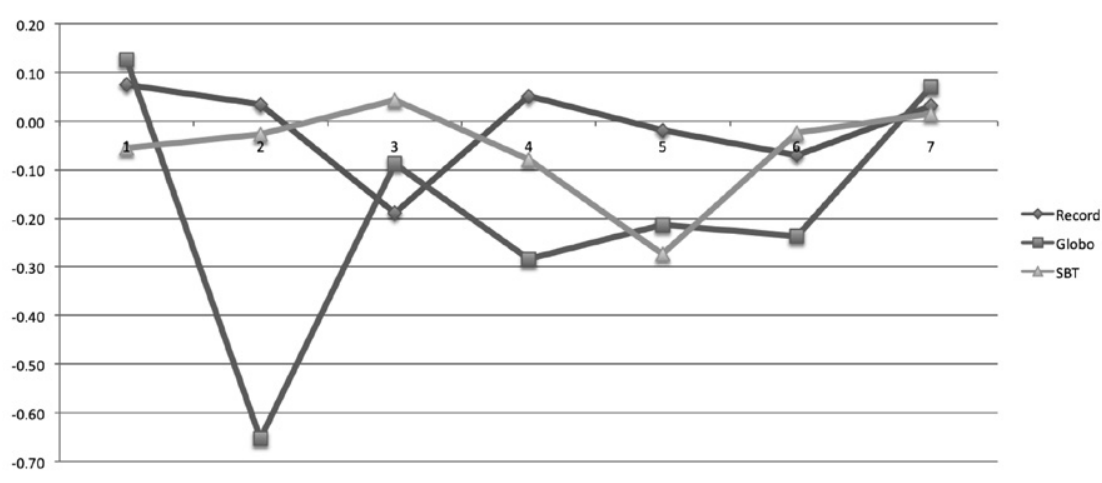

Percebe-se que no período analisado todos os dias oscilaram, o que manteve a tendência identificada nas análises referentes ao ano de 2012 . O mesmo é válido para as variações minuto a minuto, que também mantêm a tendência de oscilação.

\section{Análise da variação diária dos dados}

Para analisar mais a fundo as variações e o comportamento dos dados do período de $1^{\circ}$ a 7 de novembro, serão detalhadas, dia a dia, as variações negativas e positivas em escala decimal, com as respectivas ocorrências em percentual.

É facilmente perceptível como e onde ocorreram as maiores variações. Em gráficos nos quais a frequência da variação é analisada numericamente, espera-se que a maior quantidade das variações ocorra nas casas decimais próximas a zero e vá diminuindo proporcionalmente à medida que se aproximam do um ponto. Nesse caso, vê-se que isso nem sempre ocorre.

Analisando as variações dos sete dias da TV Record, percebe-se uma tendência na qual as variações negativas variam mais em casas decimais distantes do zero, enquanto as variações positivas ocorrem mais próximas do zero, como é esperado.

Isso acontece principalmente nas variações negativas, com destaque para os dias 1, 5, 6, de forma mais acentuada, e 2, 4 e 7, de forma mais sutil. 
Apenas o dia 3 mantém um decréscimo da curva dentro do esperado, com oscilações pequenas do $0,60 \mid--0,70$ para $0,70 \mid--0,80^{5}$. Já quanto às curvas da variação positiva, os dias 5 , de forma acentuada, e 4 , de forma mais sutil, fogem do padrão. As demais, com pequenas variações, seguem o comportamento esperado da curva.

No caso do SBT há mais equilíbrio. As variações positivas oscilam um pouco mais do que as negativas, mas com poucas diferenças substanciais. Na média apenas uma casa decimal foge do comportamento padrão. A principal exceção aconteceu no dia 5, quando a variação negativa teve um decréscimo anormal um pouco mais acentuado.

Por outro lado, a Globo apresentou variações fora do padrão em todos os dias analisados. Apenas a variação negativa do dia 6 se aproxima de um decréscimo linear, com duas pequenas exceções (0,30|-- 040 e 0,90|- 1,00). Nos demais dias, chama a atenção a variação em casas decimais distante do zero, especialmente entre $1,00 \mid--2,00$. No caso das variações positivas, apenas o dia 4, único dia em que a variação consolidada em relação à prévia foi negativa, não ocorreu uma variação significativa. Todos os demais dias apresentaram substancial variação nessa faixa. No caso da variação negativa, apenas os dias 4 e 7 se destacam com oscilações representativas nessa faixa.

\section{Conclusão}

Através da presente análise, percebe-se que os índices da audiência consolidada diferem daqueles fornecidos previamente, em tempo real. Isso acontece tanto nos dados minuto a minuto quanto nas médias diárias e mensais. No caso dos dados minuto a minuto, foram identificadas variações maiores do que nas médias diárias e mensais. Como o Ibope consolida as informações de um dia para o outro, pode-se concluir que as informações prévias sobre a audiência não condizem com a realidade, caso contrário não haveria necessidade de correções.

5 As notações |-- e --| são utilizadas para mostrar qual extremo dos dados é incluído na faixa de valores, o que é dado pelo símbolo |. Dessa forma, 0,60|-- 0,70 significa que o número 0,60 está incluído na faixa e o 0,70 não. 
As variações foram diferentes de emissora para emissora no ano de 2012. No caso do SBT, no primeiro semestre foram constantes as correções que aumentaram a audiência consolidada em relação à prévia. No segundo semestre aconteceu o contrário. A TV Globo foi a emissora com maior variação positiva na média mensal, em que, em oito meses, a audiência consolidada foi maior do que prévia. A Record foi a emissora com maior variação negativa na média mensal, com sete meses que apresentaram dados consolidados inferiores aos prévios.

Estatisticamente, as variações entre a audiência consolidada e a prévia tendem a se anular ao se considerar períodos maiores de tempo, como um ano. Variações na média anual inferiores ou próximo a 1\%, como as identificadas na análise dos dados referentes a 2012, têm alta probabilidade de ocorrer. Ou seja, do ponto de vista da estatística, é possível, e aceitável, pequenas variações como estas em períodos de tempo maiores.

No entanto, o mesmo não acontece em análise do comportamento diário dessa variação. No ano de 2012, com uma exceção, todos os dias tiveram variações, mais acentuadas em alguns casos, e menos em outros. No caso específico da TV Record, emissora com mais da metade da programação ao vivo, se considerarmos todo o ano, a probabilidade de variação, tanto positiva quanto negativa, é de $50 \%$ na média diária. Portanto, é uma certeza de que os dados consolidados serão diferentes daqueles apresentados na prévia. Ou seja, a prévia não corresponde ao comportamento real da audiência no momento indicado pelos dados.

Ao se analisar detalhadamente os dados referentes à audiência minuto a minuto, como os da primeira semana de novembro, percebe-se grandes e significativas variações. Durante a semana de $1^{\circ}$ a 7 de novembro, praticamente todos os minutos variaram positiva ou negativamente. Na média, apenas um minuto por dia não variou entre a audiência prévia e a consolidada, o que é, estatisticamente, insignificante.

Além disso, tanto na semana do dia $1^{\circ}$ a 7 de novembro de 2012 quanto na semana de 10 a 16 de janeiro de 2013 , verificaram-se elevadas va- 
riações nos índices minuto a minuto da audiência consolidada em relação à prévia. Variações superiores a $10 \%$ (ou seja, a audiência consolidada foi $10 \%$ maior ou menor do que a prévia) são comuns em todos os dias. Em média, mais de 60 minutos por dia possuíram variações superiores a 10\%, chegando à casa dos $40 \%$ em alguns casos. Esse tipo de variação, e consequente correção, não é comum, nem aceitável, em pesquisas estatísticas (Magalhães e Lima, 2011).

Analisando apenas os índices de audiência prévia e consolidada não é possível inferir o porquê da ocorrência de tantas variações. Os livros de estatística apontam que uma amostra corretamente construída e o uso de técnicas coerentes e confiáveis de coleta de dados não deveriam gerar distorções do porte como as que foram identificadas nesta pesquisa, especialmente nos índices minuto a minuto (Magalhães e Lima, 2011; Mattar, 2007; Webster, Phalen e Lichty, 2006; Jauset, 2000).

As variações superiores a $10 \%$ podem indicar uma série de problemas com a amostra, coleta, envio e tratamento dos dados. Problemas com a entrada das informações pelas pessoas que compõe o painel amostral, restrições na rede para envio dos dados e limites no banco de dados do Ibope, poderiam explicar a inexatidão dos números da audiência prévia. No entanto, não é possível fazer qualquer inferência concreta sem acesso às informações e metodologias de coleta e tratamento das informações por parte do Ibope. Em outras palavras, para buscar explicações sobre o porquê de tamanhas variações, é necessário acesso a informações não públicas sobre o método da definição da amostra, coleta dos dados, tecnologias de envio dos dados e tratamento das informações no banco de dados do Ibope.

No ano de 2012, apenas em um dia, no mês de julho, a audiência consolidada foi igual à prévia. Esse fato foi verificado nos índices da TV Globo. Nos demais casos, sempre houve variação. Baseados nos índices de audiência dos 366 dias do ano de 2012, não é possível estabelecer alguma tendência para balizar o uso concreto e correto das informações prévias. Sabe-se apenas que ocorrerão alterações. Portanto, é um risco usar estratégica e comercialmente as informações da audiência prévia. 
Além disso, a análise dos dados aponta para determinados padrões de comportamento, que podem durar três a quatro meses (no caso das variações negativas da Globo e da Record, respectivamente), ou seis meses (no caso do SBT, que registrou um primeiro semestre com variação positiva significativa e um segundo semestre negativo).

Quotidianamente, uma emissora de TV não pauta sua programação pela média anual dos índices de audiência, mas pelas informações disponíveis no momento em que uma decisão deve ser tomada. Sob esse ponto de vista, as constantes variações dos índices consolidados em relação aos dados prévios comprometem tanto a credibilidade das informações quanto a base usada para tomada de decisão.

Como estas são as informações disponíveis para gerenciar a programação, pode-se concluir que os programas que usaram os dados prévios da audiência para tomar decisões estratégias referentes à programação se basearam em dados incorretos, não condizentes com a realidade. Dessa forma, as decisões tomadas têm alta probabilidade de erro, pois as informações em tempo real estavam incorretas.

A medição comercial da audiência está baseada em métodos quantitativos, que buscam essencialmente identificar o tamanho e a composição da audiência (Bermejo, 2007). São dados essenciais para determinar as estratégias empresariais tanto dos anunciantes quanto dos próprios programas de TV. Larrañaga (1998) explica que a medição da audiência não busca conhecer a opinião ou atitude das audiências, mas sim avaliar a programação emitida através da quantificação dos telespectadores que ela pode ter.

A visão de Larrañaga, que é a base das emissoras comerciais de TV, induz à seguinte conclusão: se o programa tem uma audiência satisfatória, ele é bom e tem potencial comercial. Caso contrário, precisará melhorar ou irá sair do ar, sendo substituído por outro, com mais potencial de atrair público (e anunciantes). Dessa forma, esse enfoque gera análises de audiência marcadas por um caráter empírico, centradas na simples quantificação de espectadores que sintonizam determinado canal ou programa de TV. 
Essa simplificação pode ser um problema para análises de audiência mais abrangentes do que a simples quantificação estatística e para estudos sobre o comportamento do público. No entanto, fornece dados concretos para o diretor de programação, que toma decisões estratégicas sobre o programa de forma técnica. Se a audiência subiu, o programa está agradando; se há queda na audiência, mudanças são necessárias.

Contudo, como esta pesquisa demonstrou, os dados de audiência real fornecidos pelo Ibope não são confiáveis. Nesse caso, não é possível concluir a qualidade do programa de TV no momento em que ele é transmitido. Apenas no dia seguinte, a partir da consolidação dos dados, pode-se avaliar se o programa agradou ou não ao público. Significa que o diretor de programação não dispõe da ferramenta da audiência em tempo real para tomar decisões. $\mathrm{O}$ fato de a audiência estar em alta, com público maior do que a emissora concorrente, pode significar que, na verdade, a audiência estava em queda e que a emissora concorrente estava com mais pessoas assistindo. Isso só será confirmado pelos dados consolidados.

Dessa forma, a direção de programação, que deveria ser uma atividade técnica dentro do escopo de uma emissora de TV, se transforma em uma área artística, na qual o sentimento do diretor de programação se torna mais importante do que os dados de audiência. Em outras palavras, o diretor de programação toma decisões às cegas, sem conhecer o que está de fato acontecendo com a audiência. Isso significa que há um prejuízo tanto para a qualidade da programação quanto para o anunciante.

A qualidade da programação fica prejudicada porque o diretor de programação não tem elementos para decidir a duração de uma determinada atração. Para bem ou para o mal, a medição da audiência em tempo real determina se um cantor, em um programa de variedades, por exemplo, está agradando ou não ao público. Normalmente, se estiver agradando, ou seja, com audiência considerada boa pela direção do programa, ele irá ficar mais tempo no ar. Sem a confiabilidade da audiência em tempo real, a decisão é tomada apenas pelo diretor de programação. Ou seja, em vez de levar em conta milhares de opiniões, apenas uma cabeça irá determinar se o cantor está agradando ou não. 
Além disso, o momento do intervalo comercial é decidido em função do comportamento do público nos dados da audiência em tempo real. Nesse caso, duas estratégias podem ser utilizadas: 1 ) atrasar o intervalo comercial para não perder público, em função da briga pela audiência com emissoras concorrentes. Normalmente a audiência cai no intervalo comercial, graças ao fenômeno do zapping, no qual as pessoas sintonizam outros canais por pouco tempo. Por isso, diretores de programação evitam intervalos comerciais quando consideram que as emissoras concorrentes têm atrações ou programas melhores no ar naquele momento (Machado, 1996).2) chamar o intervalo comercial nos picos de audiência. Teoricamente, quanto maior a audiência do programa, mais pessoas assistirão à propaganda durante o intervalo comercial. Por isso, diretores de programação costumam chamar o intervalo comercial nos momentos de maior audiência, o que satisfaz e fideliza os anunciantes. No entanto, com a ausência de informações, o que gera uma tomada de decisão não técnica, há prejuízos para as estratégias comerciais, tanto da programação da TV quanto dos anunciantes.

Essa relativização do uso dos dados da audiência tem gerado questionamentos em vários setores da sociedade brasileira e da cadeia de valor do produto televisão. As informações fornecidas pelo Ibope não têm suprido todas as necessidades das emissoras de TV e dos anunciantes. No Brasil, os dados de audiência são constantemente questionados. Problemas como este, apontados nesta pesquisa, fornecem mais subsídios para quem questiona os métodos e dados do Ibope e de outros institutos de medição de audiência mundo afora.

\section{Referências}

Bermejo, F. (2007). The internet audience: constituion \& measurement. Nova York: Peter Lang.

Cruz, R. (2008). tv digital no Brasil: tecnologia versus política. São Paulo: Senac.

Ibope. (2013). Instituto Brasileiro de Opinião Pública e Estatística. Disponível em: www.ibope.com.br [Data da consulta $1^{\circ}$ nov. 2013]. 
Iglesias, F. (1985). "Investigación de audiencias en televisión y mejora de calidad de los contenidos". Em: Documentación de las Ciencias de Za Información, IX. Edit. Ijniv. Compí. Madri.

Jauset, J. A. (2000). La investigación de audiencias en televisión: fundamentos estadísticos. Barcelona: Paidós.

Larrañaga, G. (1998). “La batalla por las audiencias”. Em: XIV Congreso de Estudios Vascos: Informazioaren Gizartea - Sociedad de la Información - Société de l'Information. Donostia: Eusko Ikaskuntza.

Machado, A. (1993). Máquina e imaginário. São Paulo: Edusp.

Magalhães, M. N. \& Lima, A. C. P. (2011). Noções de probabilidade e estatística. São Paulo: Edusp.

McQuail, D. (1997). Audience Analysis. Londres: Sage Publications.

Mattar, F. N. (2007). Pesquisa de marketing: edição compacta. São Paulo: Atlas.

Webster, J. G.; Phalen, P. F. \& Lichty, L. W. (2006). Rating Analysis: The Theory and Practice of Audience Research. 3. ed. Londres: Lawrence Erlbaum Associates, Inc. 